\title{
Actualism and possibilism
}

\section{TRAVIS TIIMMERMAN AND YISHAI COHEN}

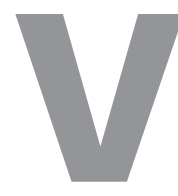

irtually all normative ethical theories hold that whether an action is morally right depends upon the alternative acts available to the agent. But what exactly are the relevant alternative acts available to an agent? The answer to this question is far from obvious once we consider facts about how an agent would freely act in various situations. To get a grip on this abstract issue, consider the following concrete case:

The Gig Brandi has been invited by her friend, Ellen, to attend her musical gig at a local bar. Brandi can easily decide to attend the gig, and then decide at the gig to be supportive of Ellen, which would be the best outcome. Unfortunately, Ellen is a mediocre musician. Consequently, Brandi would not in fact decide to be supportive of Ellen if she decided to attend her gig due to being irritated with Ellen's performance - even though she could decide at the gig to be supportive. Since Ellen would be deeply hurt, this would be the worst outcome. Brandi could alternatively decide not to attend Ellen's gig, which would be better than the worst outcome, yet worse than the best outcome.
To be sure, Brandi can decide to attend the gig, and once there decide to be supportive of Ellen. However, suppose we know that that's just not what Brandi would do if she were to attend. Here's the tricky philosophical question. Is Brandi morally obligated to accept or decline the invitation to Ellen's gig?

Actualists say that Brandi is obligated to decline because what would actually happen if Brandi declines is better than what would actually happen if she accepts. Possibilists, by contrast, say that Brandi is obligated to accept because accepting is part of the best act-set Brandi can perform. So, unlike actualists, possibilists think that facts about how an agent would freely act don't affect an agent's obligations.

Both views are subject to serious problems. First, actualism allows agents to avoid incurring moral obligations because of rotten dispositions. Brandi avoids incurring an obligation to attend Ellen's gig because Brandi is disposed to be mean. But people should not be able to get out of doing good things just because they're disposed to do bad things. Second, actualism often prescribes horrible behaviour. For instance, actualism entails that Brandi is obligated to murder Ellen if not murdering Ellen would later result in murdering Brandi's two other friends (a worse 
outcome). Actualism prescribes this even though Brandi can freely decide to murder no one.

Third, possibilism holds that agents are sometimes obligated to act in ways that would result in the worst outcome. Suppose that if Brandi were to attend Ellen's gig, Brandi would become so irritated that she would murder Ellen, even though Brandi could attend and behave. Intuitively,

\section{Actualism allows agents to avoid incurring moral obligations because of rotten dispositions}

Brandi is then obligated to decline Ellen's invitation. But possibilism holds that since it's possible for Brandi to attend the gig and behave, Brandi is obligated to accept the invitation, even though this would result in Ellen's murder.

In light of these problems, philosophers have proposed alternatives to actualism and possibilism. Securitists say that facts about how one would freely act are only relevant to one's obligations if one presently lacks a certain kind of control over one's future free actions. To illustrate, suppose that no matter what Brandi intends to do right now, she would freely fail to be supportive of Ellen's musical performance. In that case, securitism says that Brandi ought to decline to attend the gig. On the other hand, if Brandi can presently ensure that she both attends the gig and is supportive of Ellen, securitism says that Brandi ought to accept the invitation, even when she would fail to be supportive of Ellen. Securitism, however, has recently been shown to be subject to the same problems that face actualism.
Another alternative, proposed by us, is hybridism. Hybrid views posit two distinct moral "oughts", which jointly track the insights of both actualism and possibilism, yet are arguably immune from the aforementioned problems. In its simplest form, hybridism says that Brandi morally ought to accept the invitation, yet practically ought to decline the invitation. Always acting in accordance with the first "ought" ensures that one fulfils all of one's moral obligations, while acting in accordance with the second "ought" ensures that one minimises wrongdoing in light of one's moral shortcomings. The practical "ought" takes Brandi's shortcomings into its prescriptions, telling Brandi to perform a wrong act now in order to prevent herself from performing an even worse act later.

There are other views in the vicinity of hybridism and securitism worth taking seriously. Ethicists have yet to figure out which view is the correct one, though increased attention to the debate could change that.

Further reading: For more on actualism, possibilism, and securitsm, see chapters 6-7 of Doug Portmore's Commonsense Consequentialism: Wherein Morality Meets Rationality. For a defence of hybridism, see our paper "Moral Obligations: Actualist, Possibilist, or Hybridist?" forthcoming in the Australasian Journal of Philosophy.

Travis Timmerman is a PhD candidate in philosophy at Syracuse University. He specialises in death, normative ethics, applied ethics and metaethics.

Yishai Cohen is a PhD candidate in philosophy at Syracuse University. He specialises in free will, philosophy of religion and ethics. 